Journal of Engineering and Applied Sciences 15 (3): 773-782, 2020

ISSN: 1816-949X

(C) Medwell Journals, 2020

\title{
Design and Performance Analysis of a 3-Phase Induction Motor for Solar Photovoltaic Fed Pumping System
}

\author{
Ahmed Mohammed Abdul Hussain and Hanan Mikhael D. Habbi \\ Department of Electrical Engineering, College of Engineering, University of Baghdad, \\ Baghdad, Iraq
}

\begin{abstract}
This study presents the efficient use of solar energy by operating Photovoltaic (PV) panels for the powering of the 3-phase Induction Motor (IM) to pump the water. The main components of solar-powered pump system are the solar panel inverter, 3-phase (IM) and circuit breaker to protection of the proposed system. The proposed system implemented and simulation the application to give power from solar to (IM) to drive the centrifugal Pump by converting the DC electric power generated from a PV panel to AC power using the 3-phase inverter. In the proposed system solar panel of $3 \mathrm{~kW}$ and 3-phase (IM) used is of 3 HP power rating. The control strategy of the 3-phase inverter is used SPWM is carried out. The simulation of the proposed system using MATLAB/Simulink Software.
\end{abstract}

Key words: PV panels, Voltage Source Inverter (VSI), 3-phase Induction Motor (IM), centrifugal pump, application, electric power

\section{INTRODUCTION}

Solar photovoltaic panels which can be used for conversion of solar energy directly into electricity for water pumping in rural agricultural purposes is concentrated. PV power systems range in size from watts to megawatts. In operation, these systems have the least environmental impact with no emissions, noise or other potentially. The major renewable sources of energy are solar, wind, biomass, fuel cell, tidal, geothermal etc. A stand-alone PV system generally consists of a PV array, a storage component, control and power processing components. PV pumps have recently received considerable attention due to major development in the field of solar cell material and technology. A number of dc motor driven PV pumps are already in use in several parts of the world. But they suffer from maintenance problems due to the presence of the commutator and brushes (Anjana et al., 2017; Pandikumar et al., 2015).

Hence, a pumping system based on an Induction Motor (IM) can be an attractive proposal where reliability and maintenance-free operations are important. Induction motors also have low weight and inertia, high efficiency and a high overload capability. Therefore, they are cheaper and more robust and less proves to any failure at high speeds. A variable frequency is required because the rotor speed depends on the speed of the rotating magnetic field provided by the stator. A variable voltage is required because the motor impedance reduces at low frequencies and consequently the current has to be limited by means of reducing the supply voltages (Ramesh et al., 2014). The output voltage obtained from solar energy is fed to three phase voltage source inverter circuit and the output of inverter is fed to 3-phase induction motor connected to the centrifugal pump for water pumping system. Simulation is carried out with solar panel inverter and 3-pahse induction simulation is carried out with solar panel inverter and 3-pahse induction motor. The detailed simulation analysis and hardwire results prototype of water pumping system (Sharma and Parakh, 2018).

This study presents a novel stand-alone solar-powered water-pumping system, especially suited for usage in rural or remote areas. The system is primarily designed to reduce both cost and complexity while simultaneously guaranteeing optimal utilization of the photovoltaic generator. The proposed solution consists of a water pump driven by a 3-phase induction motor and inverter to controlled by using Sinusoidal Pulse Width Modulation (SPWM) technique. The photovoltaic array is directly connected to the dc bus of the inverter with no intermediate power conversion stages (Venkatesh and Muthukumar, 2017).

Hence, there is a need to investigate the maximum efficiency operation of single stage inverter fed (IM) based PV water pumping system for its steady state and dynamic performance. Figure 1 shows the block diagram of the solar based water pump. The input current and input voltage from the PV array is taken to calculate the output power of PV panels (Jain et al., 2016).

Corresponding Author: Ahmed Mohammed Abdul Hussain Department of Electrical Engineering, College of Engineering, University of Baghdad, Baghdad, Iraq 


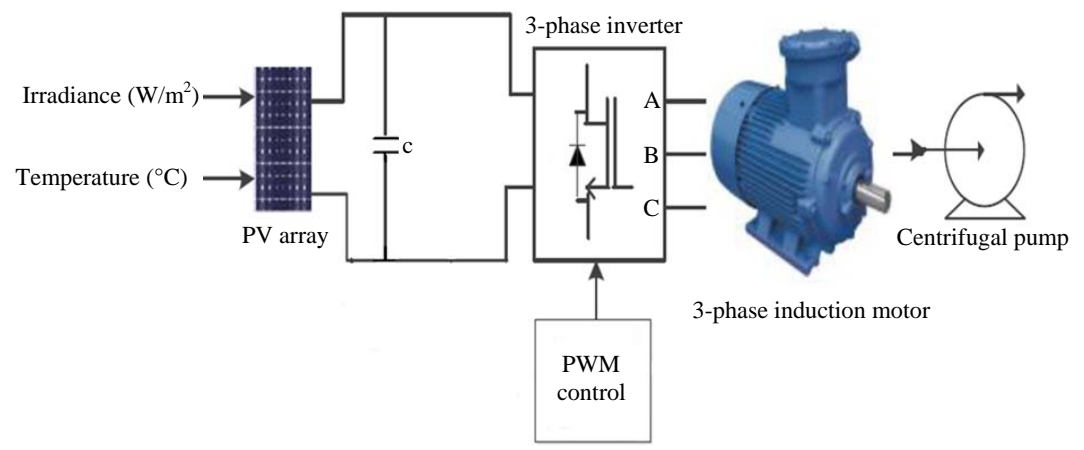

Fig. 1: Block diagram of solar pumping system with (3-phase I.M) (Jain et al., 2016)

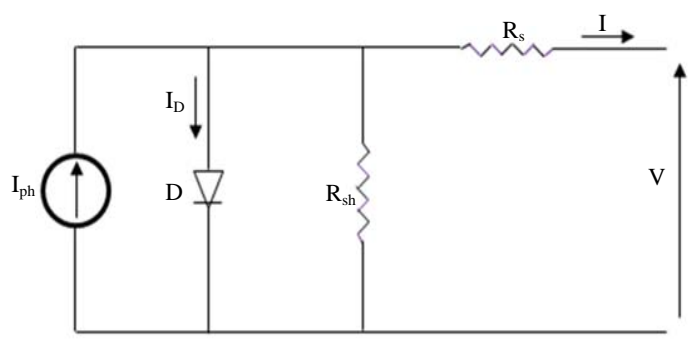

Fig. 2: Equivalent circuit of photovoltaic cell (Chenni et al., 2006)

\section{MATERIALS AND METHODS}

\section{Photovoltic panels}

Electrical model for a photovoltic cell: The PV cell equivalent circuit consists of a photo current source, diode, a resistor in parallel representing leakage current and a resistor in series characterize an internal resistance to the current flow as shown in Fig. 2 (Chenni et al., 2006). The photovoltaic array chosen is a $1 \mathrm{STH}-320-\mathrm{P}$ to provide $320 \mathrm{~V}$. The PV cell current-voltage characteristic equation is given as (Saini and Dubey, 2017):

$$
\mathrm{I}=\mathrm{I}_{\mathrm{ph}}-\mathrm{I}_{\mathrm{o}}\left(\exp \left[\frac{\mathrm{q}\left(\mathrm{V}+\mathrm{I} * \mathrm{R}_{\mathrm{s}}\right)}{\mathrm{kTA}}\right]-1\right)-\frac{\mathrm{V}+\mathrm{I} * \mathrm{R}_{\mathrm{s}}}{\mathrm{R}_{\mathrm{sh}}}
$$

Where:

I : The cell output current (A)

$I_{\mathrm{ph}}$ : The light-generated current or photocurrent (A)

$\mathrm{I}_{\mathrm{o}} \quad$ : The diode reverse saturation current (A)

$\mathrm{V}$ : The cell output Voltage (V)

$\mathrm{R}_{\mathrm{sh}}$ : The shunt Resistance $(\Omega)$

$\mathrm{R}_{\mathrm{s}}$ : The series Resistance $(\Omega)$

$\mathrm{q}$ : The electron charge $(\mathrm{q}=1.6 \times 10-19$ Coulomb $)$

$\mathrm{k}$ : The Boltzmann's constant $(\mathrm{k}=1.38 \times 10-23 \mathrm{~J} / \mathrm{K})$

$\mathrm{T}$ : The cell temperature (Degree)

A : The diode ideality constant

For an ideal PV cell, there is no leakage to ground and there is no series losses, i.e., $R_{\mathrm{sh}}=\infty$ and

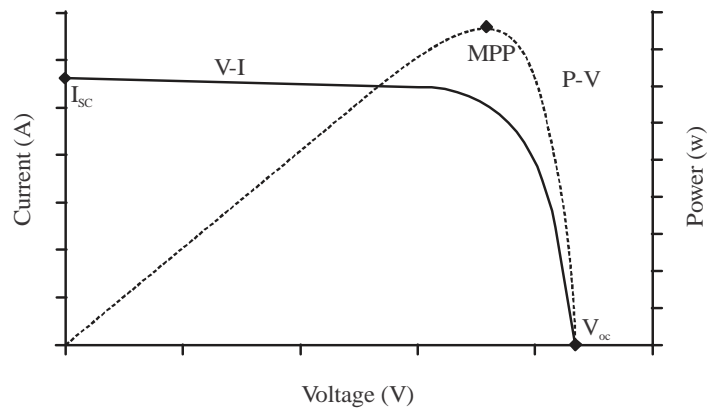

Fig. 3:I-V and P-V characteristics curve of photovoltaic cell (Morales, 2010)

$\mathrm{R}_{\mathrm{s}}=0$. The PV cell current-voltage characteristic equation can be rewritten to be (Zakzouk and EzzEldin, 2015):

$$
I=I_{p h}-I_{o}\left(\exp \left(\frac{q V}{k T A}\right)-1\right)
$$

The I-V and P-V characteristics of a typical solar cell are as shown in Fig. 3.Three important parameters from the curves, PV open circuit Voltage $\left(\mathrm{V}_{\mathrm{oc}}\right)$, PV short circuit current (Isc) and PV Maximum Power Point (MPP). The current of PV panel will drop slowly when the voltage of PV panel is smaller than the MPP Voltage $\left(\mathrm{V}_{\mathrm{mpp}}\right)$ but the current will drop quickly when the voltage of PV panel is greater than Vmpp, the PV current will reach its maximum $\left(\mathrm{I}_{\mathrm{mpp}}\right)$ when the voltage of PV panel reaches $\mathrm{V}_{\text {mpp }}$ (Morales, 2010).

Design of photovoltic panels: The PV array with a rating of $\mathrm{P}_{\mathrm{mpp}}=2.7 \mathrm{~kW}$ is designed for the proposed pumping system. The specification of the module is given in Table 1 The output voltage of Solar array is $320 \mathrm{~V}$. When given $320 \mathrm{~V}$ as input to the inverter we get (a RMS A.C voltage) which would drive the 3-phase induction motor. The current at MPP is calculated as (Kumar and Singh, 2017): 
J. Eng. Applied Sci., 15 (3): 773-782, 2020

Table 1: Characteristics of photovoltaic module at STC ( $\mathrm{G}=1000$ $\mathrm{W} / \mathrm{m}^{2}$ and $\mathrm{T}=25^{\circ} \mathrm{C}$ )

\begin{tabular}{lcc}
\hline Parameters & Values & Units \\
\hline Maximum Power $\left(\mathrm{P}_{\max }\right)$ & 320 & $\mathrm{~W}$ \\
Maximum Voltage $\left(\mathrm{V}_{\text {mpp }}\right)$ & 37.7 & $\mathrm{~V}$ \\
Maximum current $\left(\mathrm{I}_{\text {mpp }}\right)$ & 8.41 & $\mathrm{~A}$ \\
Short circuit current $\left(\mathrm{I}_{\text {sc }}\right)$ & 8.98 & $\mathrm{~A}$ \\
Open circuit Voltage $\left(\mathrm{V}_{\text {oc }}\right)$ & 46 & $\mathrm{~V}$ \\
No. of cells connected in series, Nss & 72 & - \\
\hline
\end{tabular}

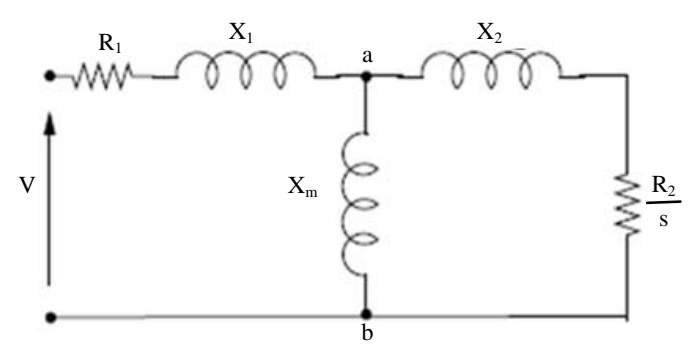

Fig. 4: Equivalent circuit of IM (Raju et al., 2008)

$$
\mathrm{I}_{\mathrm{mpp}}=\frac{\mathrm{P}_{\mathrm{mpp}}}{\mathrm{V}_{\mathrm{mpp}}}=\frac{2.7 * 1000}{320}=8.44
$$

No. of modules in series is calculated as:

$$
\mathrm{N}_{\mathrm{s}}=\frac{\mathrm{V}_{\mathrm{mpp}}}{\mathrm{V}_{\mathrm{m}}}=\frac{320}{37.7}=8
$$

Similarly number of modules in parallel is calculated as:

$$
\mathrm{N}_{\mathrm{p}}=\frac{\mathrm{I}_{\mathrm{mpp}}}{\mathrm{I}_{\mathrm{m}}}=\frac{8.44}{8.41}=1
$$

By connecting 8 modules in series and 1 modules in parallel ensures the required design for the proposed system.

Design of DC link capacitor: A small capacitor connected across the SPV array serves as the DC link capacitor of VSI. This capacitor carries the ripple current which is given as (Morales, 2010):

Where:

$$
\text { Ic }=\mathrm{I}_{\mathrm{pv}}-\mathrm{I}_{\mathrm{dc}}
$$

$\mathrm{I}_{\mathrm{pv}}: 8.41 \mathrm{~A}$ which is the PV array current at MPP $\mathrm{I}_{\mathrm{dc}}$ : The DC link current of VSI.

The worst condition is presumed at which $\mathrm{i}_{\mathrm{dc}}$ is zero, to estimate the ripple content in the capacitor current, i.e:

$$
\text { Ic }==\mathrm{I}_{\mathrm{pv}}=8.41 \mathrm{~A}
$$

The capacitor required is then given by (Kumar and Singh, 2017):
Table 2: Specifications of the 3-phase induction motor

\begin{tabular}{ll}
\hline Parameters & Values \\
\hline Rated power & $2.2(\mathrm{kw})$ \\
Rated voltage & $380(\mathrm{~V})$ \\
Rated speed & $1480(\mathrm{rpm})$ \\
No. of poles & 4 \\
Winding & Star connected \\
Resistance & $\mathrm{R}_{1}=1.115 \Omega, \mathrm{R}_{2}=1.083 \Omega$ \\
Inductance & $\mathrm{X}_{1}=\mathrm{X}_{2}=5.974(\mathrm{mH}), \mathrm{X}_{\mathrm{m}}=203.7(\mathrm{mH})$ \\
\hline
\end{tabular}

$$
\mathrm{C}=\frac{\mathrm{I}_{\mathrm{pv}}}{\mathrm{f}_{\mathrm{sw}} * \Delta \mathrm{V}_{\mathrm{pv}}}=\frac{8.41}{(10000 * 8 * 37.7)} 3 \mu \mathrm{F}
$$

Where:

$\mathrm{f}_{\mathrm{sW}}$ : The switching frequency of VSI and

$\Delta \mathrm{V}_{\mathrm{pv}}$ : The ripple content in PV Voltage, a high switching frequency results in a reduction in the size of DC link capacitor

Eqvalunt circuit of 3-phase (IM): The equivalent circuit of the 3-phase IM shown in Fig. 4. The exact equations are used in computing the steady state motor operating point. Thevenin's equivalent circuit at terminals ' $a$ ' and 'b' of Fig. 5 can be represented by a voltage source VTh and impedance ZTh as given by the following equations (Raju et al., 2008):

$$
\mathrm{V}_{\mathrm{Th}}=\frac{\mathrm{VjX}_{\mathrm{m}}}{\mathrm{R}_{1}+\mathrm{j}\left(\mathrm{X}_{1}+\mathrm{X}_{\mathrm{m}}\right)}
$$

$$
\begin{gathered}
\mathrm{Z}_{\mathrm{Th}}=\mathrm{R}_{\mathrm{Th}}+\mathrm{j} \mathrm{X}_{\mathrm{Th}} \\
\mathrm{R}_{\mathrm{Th}}=\frac{\mathrm{R}_{1} \mathrm{X}_{\mathrm{m}}^{2}}{\mathrm{R}_{1}^{2}+\left(\mathrm{X}_{1}+\mathrm{X}_{\mathrm{m}}\right)^{2}} \\
\mathrm{X}_{\mathrm{Th}}=\frac{\mathrm{R}_{1}^{2} \mathrm{X}_{\mathrm{m}}+\mathrm{X}_{1} \mathrm{X}_{\mathrm{m}}\left(\mathrm{X}_{1}+\mathrm{X}_{\mathrm{m}}\right)}{\mathrm{R}_{1}^{2}+\left(\mathrm{X}_{1}+\mathrm{X}_{\mathrm{m}}\right)^{2}}
\end{gathered}
$$

The Torque $\mathrm{T}$ developed by the motor is given by:

$$
\mathrm{T}=\frac{3}{\omega_{\mathrm{s}}} \frac{\mathrm{R}_{2}}{\mathrm{~s}} \frac{\mathrm{V}_{\mathrm{th}}^{2}}{\left(\mathrm{R}_{\mathrm{Th}}+\frac{\mathrm{R}_{2}}{\mathrm{~s}}\right)^{2}+\left(\mathrm{X}_{\mathrm{Th}}+\mathrm{X}_{2}\right)^{2}}=\mathrm{k} \omega^{2}
$$

where, $\mathrm{k}$ is the centrifugal pump constant. For a centrifugal water pump by using affinity law the attributes of the pump can be discovered as (Jones, 2013) (Table 2):

$$
\mathrm{k}=\frac{\mathrm{T}}{\mathrm{w}^{2}}=\frac{3}{(2 * \pi * 1480 / 60)^{2}}=1.25 * 10^{-4} \frac{\mathrm{N} \cdot \mathrm{m}}{(\mathrm{rad} / \mathrm{sec})^{2}}
$$

where, $\mathrm{T}$ is the torque of water pump which is equivalent to the torque offered by the induction motor under unfaltering state operation and $\omega$ is the rotational speed of 


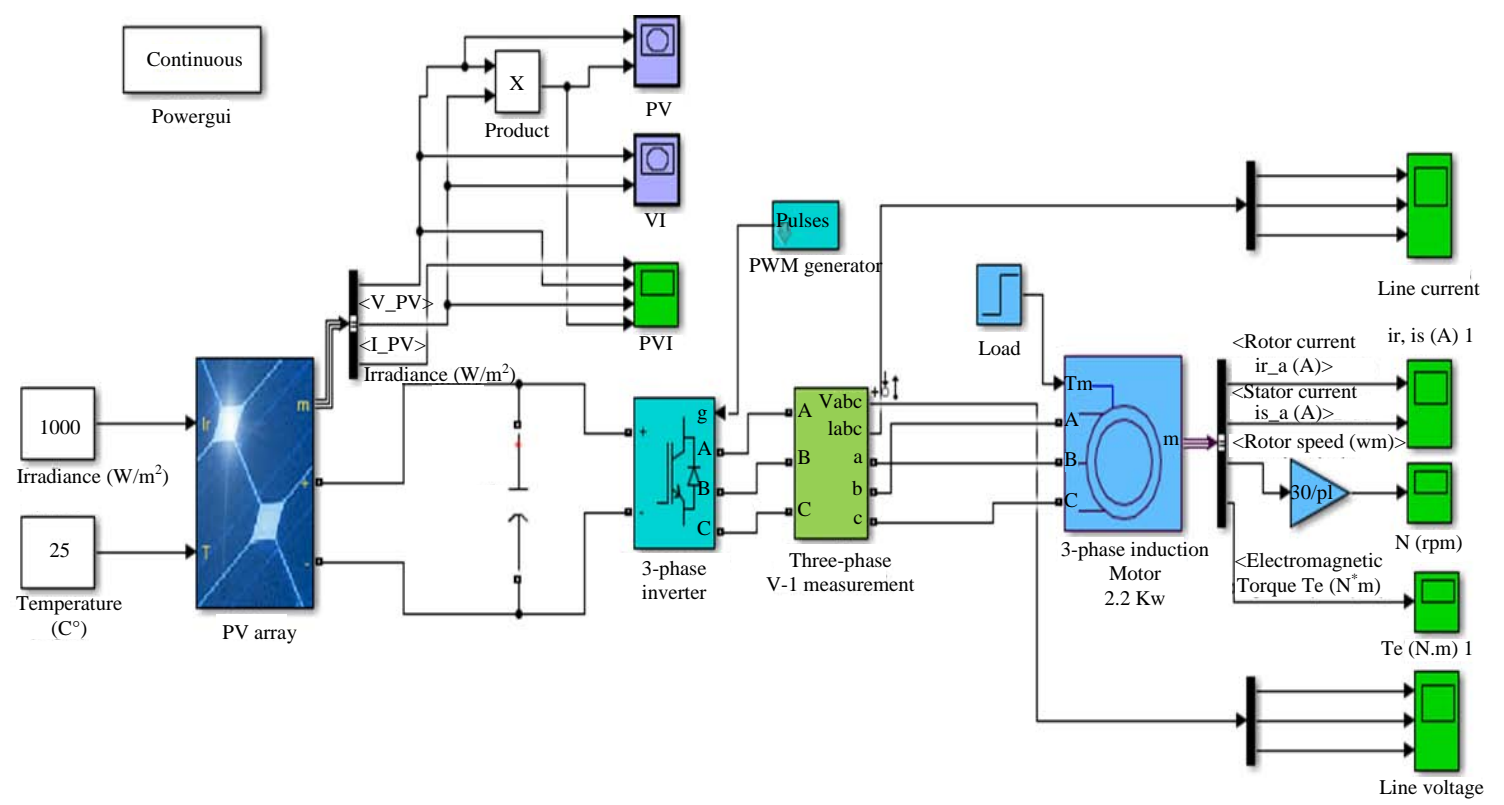

Fig. 5: MATLAB/Simulink diagram of the PV array fed pumping system with 3-phase IM

the rotor in rad/sec. Since, the water pump is a centrifugal pump type, the load torque is also constant. For recreation reason, the appraised torque and evaluated speed of the induction motor are $3 \mathrm{~N}-\mathrm{m}$ and $1480 \mathrm{rpm}$.

\section{RESULTS AND DISCUSSION}

MATLAB modelling and simulation result: Figure 6 shows the simulation diagram of the PV fed pumping system with the 3-phase IM. Here, the PV array with the DC link capacitor supplies the 3-phase inverter feeding the 3-phase IM. The same type of control, namely the Sinusoidal Pulse Width Modulation (SPWM). The MATLAB result of PV based system is shown the P-V curves and I-V curves in Fig. 7. Figure 8 exhibits the voltage, Vpv, current, Ipv and power, Ppv of solar PV array at an irradiance of $1 \mathrm{~kW} / \mathrm{m}^{2}$ (Jones, 2013).

The 3-phase induction motor receives $240 \mathrm{~V}_{\mathrm{ac}}$ from inverter for its operation to which the pump load constant is connected. The first and two simulation outputs result is the line voltage and currents as shown in Fig. 9 and 10. The above is the output from the Inverter used in our System. It is clearly visible that our system providing a perfect 3-phase output voltage and current which can be used to run the Induction motor. Thus the output from the inverter is the final output of our system. It is said, so because the inverter system is the last stage of power modification in our system (Singh and Khanchandani, 2008). The next two wave forms are the variation of torque and the speed with respect to time. The system reaches to the speed of $1480 \mathrm{rpm}$ at $0.42 \mathrm{sec}$ (Fig. 11 and 12).
The speed of the 3-phase induction motor is dependent on frequency of the supply voltage. Frequency of the supply voltage is maintained constant by using SPWM technique. The torque of 3-phase induction motor is directly proportional to square of the supply voltage. The supply voltage is from PV source which is dependent on solar irradiation. Due to dips and spikes there are some oscillations or fluctuations in the steady state of torque of induction motor. But oscillations in the transient state are due to parameters of stator and rotor (Kumar and Saikishore, 2013). Due to low rotor resistance, the machine started with higher jerks, i.e., the fluctuations in the transient period were more. The stator resistance must be kept as low as possible. The stator and rotor currents as shown in Fig. 13.

Experimentation and results: This study also shows the implementation of the system in practically by using three phase Induction Motor (I.M). A solar panels arrays were used as shown in Fig. 14, the number of PV equal 10 only eight panels were connected in series to achieve the voltages required to operate the 3 -phase inverter since that a single panel of $320 \mathrm{~W}$ and it is connected to the 3-phase inverter in order to operate the 3-phase (I.M) as rated speed. Where $\mathrm{Ns}=8$ and $\mathrm{Np}=1$.

Various measuring devices were used to measure the intensity of solar radiation (solar power meter) and to measure the temperature of the cell (temperature sensor) and measuring the speed of the (I.M) using a (taco meter) as shown in Fig. 15. Also using sine wave filters to obtain pure sin waveforms. The whole system as shown in Fig. 16.

The experimental result of this system for different irradiance and temperature is obtained the line voltages 

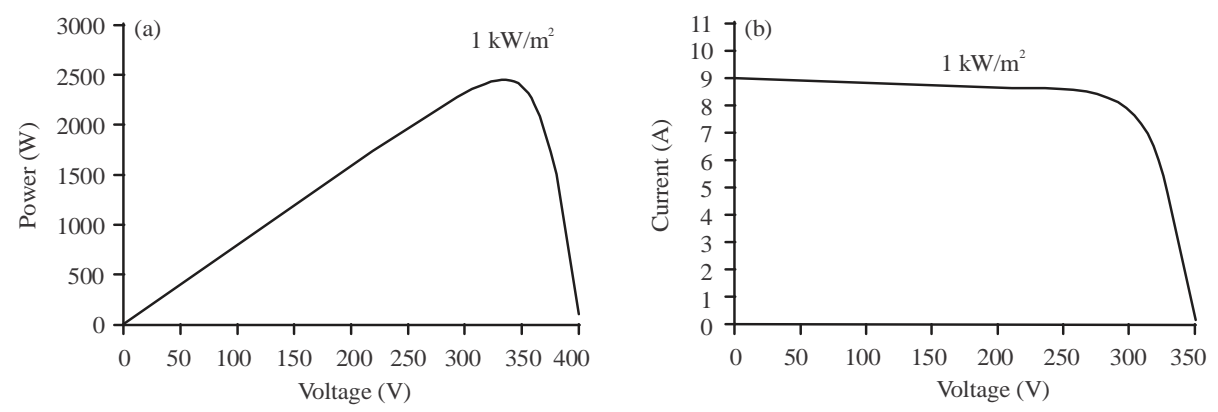

Fig. 6(a, b): P-V and I-V characteristics curve of photovoltaic array at $\mathrm{G}=1000 \mathrm{~W} / \mathrm{m}^{2}, \mathrm{~T}=25^{\circ}$
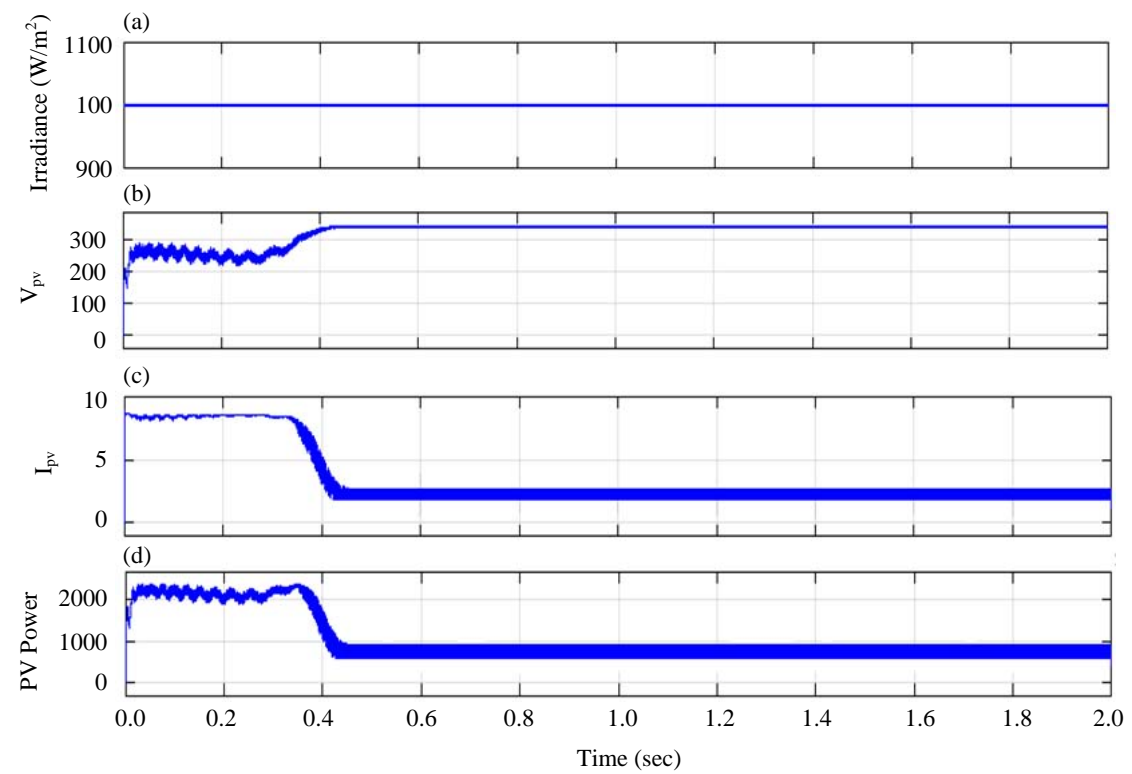

Fig. 7(a-d): Starting and steady state performances of solar PV array at $1000 \mathrm{~W} / \mathrm{m}^{2}$
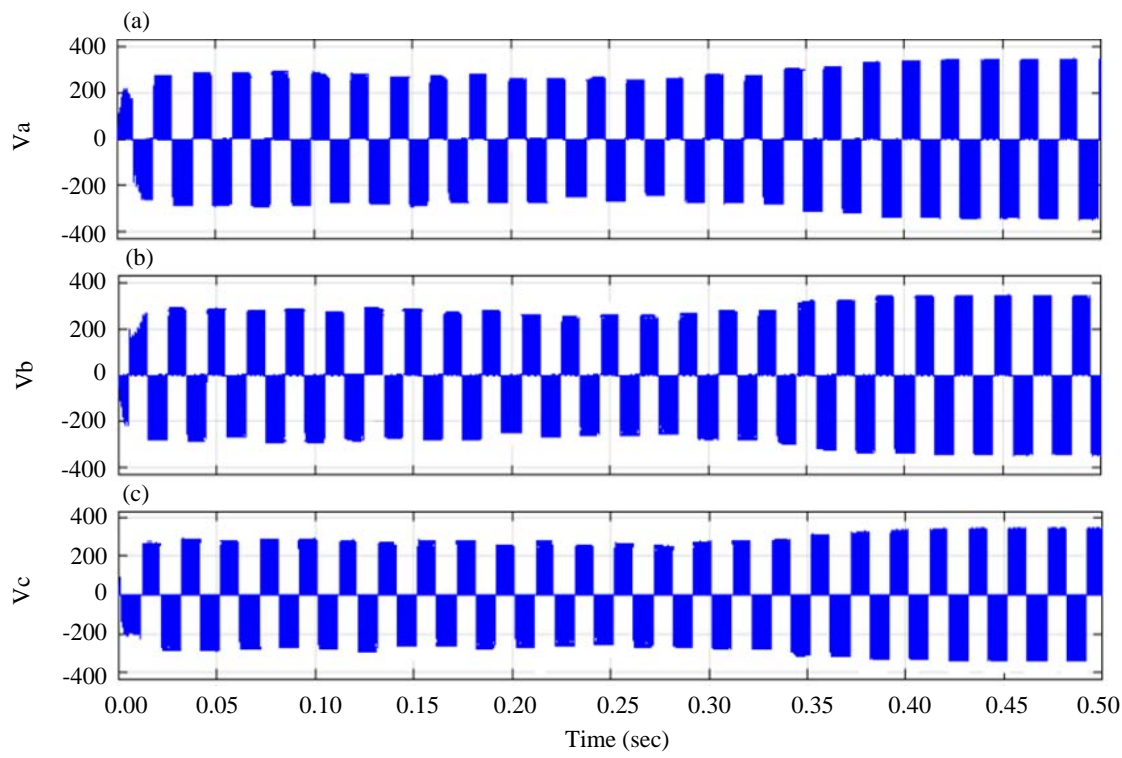

Fig. 8(a-c): Output line voltage of 3-phase inverter 

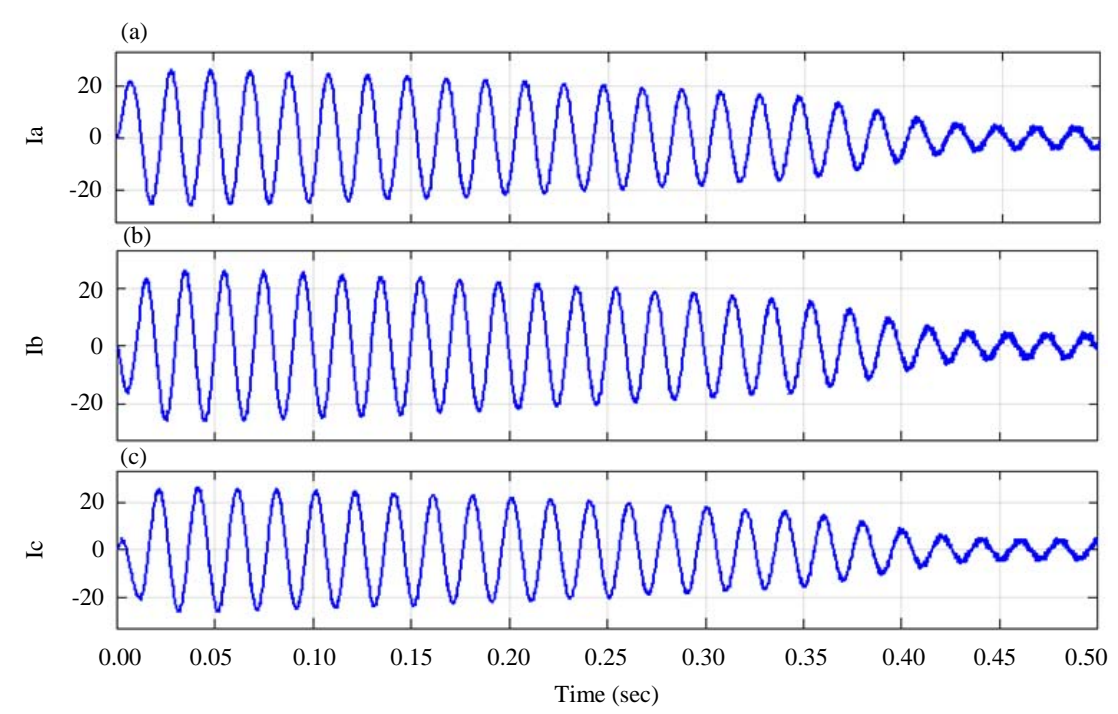

Fig. 9(a-c): Output line current of 3-phase inverter

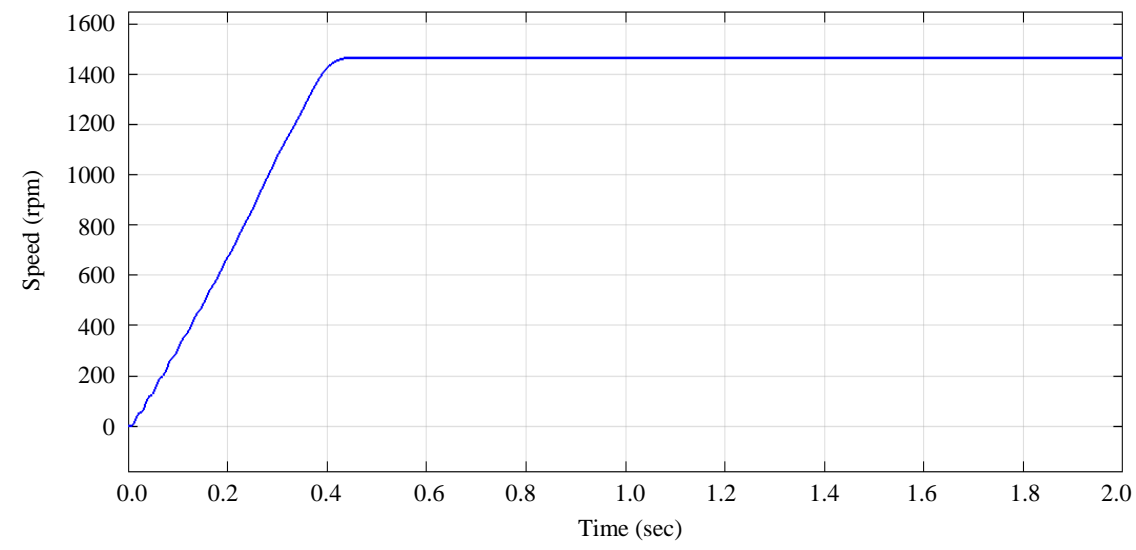

Fig. 10: Speed response of 3-phase I.M

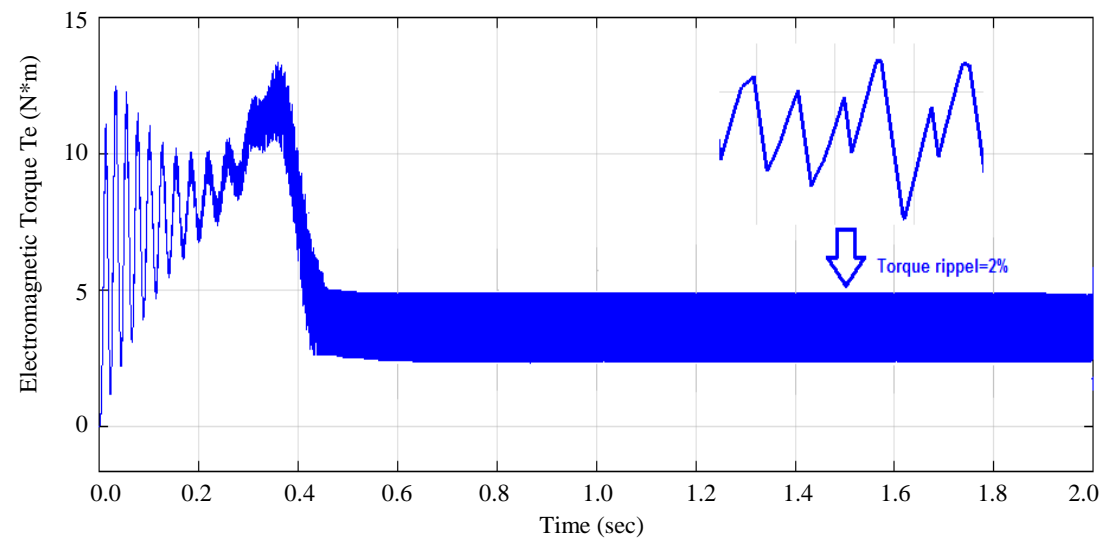

Fig. 11: Electromagnetic Torque $\left(\mathrm{T}_{\mathrm{e}}\right)$ of 3-phase I.M

and phase voltages with different speed of (I.M). Measurements are obtained by using the oscilloscope spectrum analyzer (ATTEN digital oscilloscope ADS
1062 CAL $60 \mathrm{MHz}$, USB storage). Figure 17 shown the output voltage from the PV panel $\mathrm{V}_{\mathrm{PV}}=40.7 \mathrm{~V}$ for $\mathrm{G}=1085 \mathrm{~W} / \mathrm{m}^{2}$ and $\mathrm{T}=40^{\circ} \mathrm{C}$. 

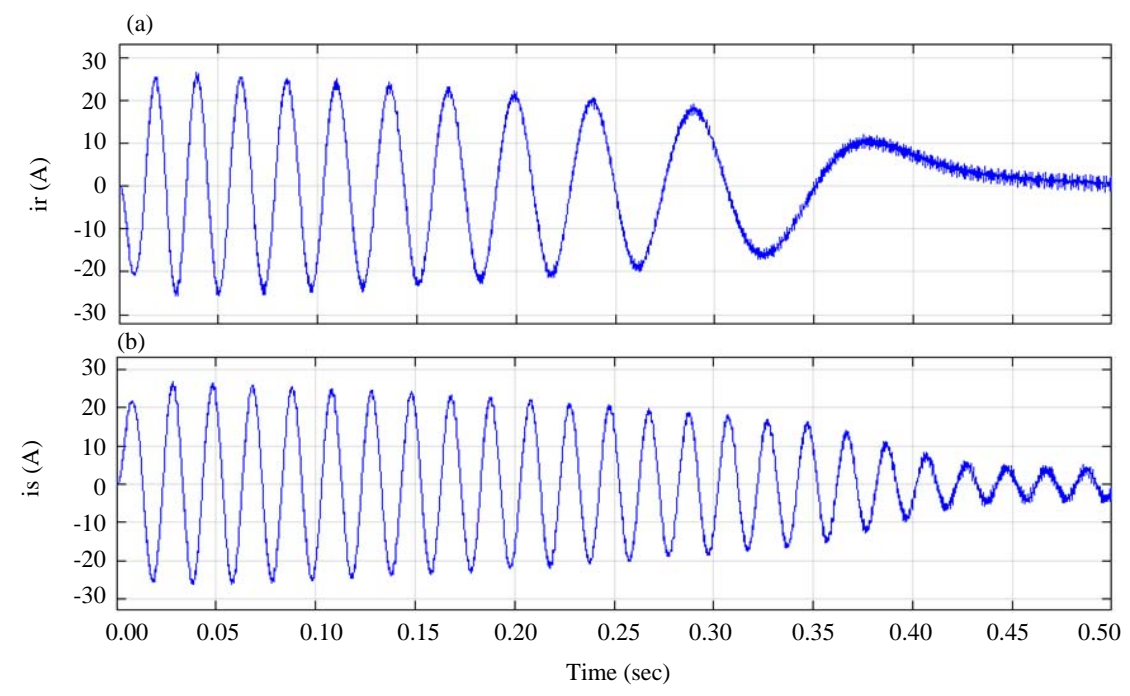

Fig. 12(a, b): Stator and rotor currents of 3-phase I.M

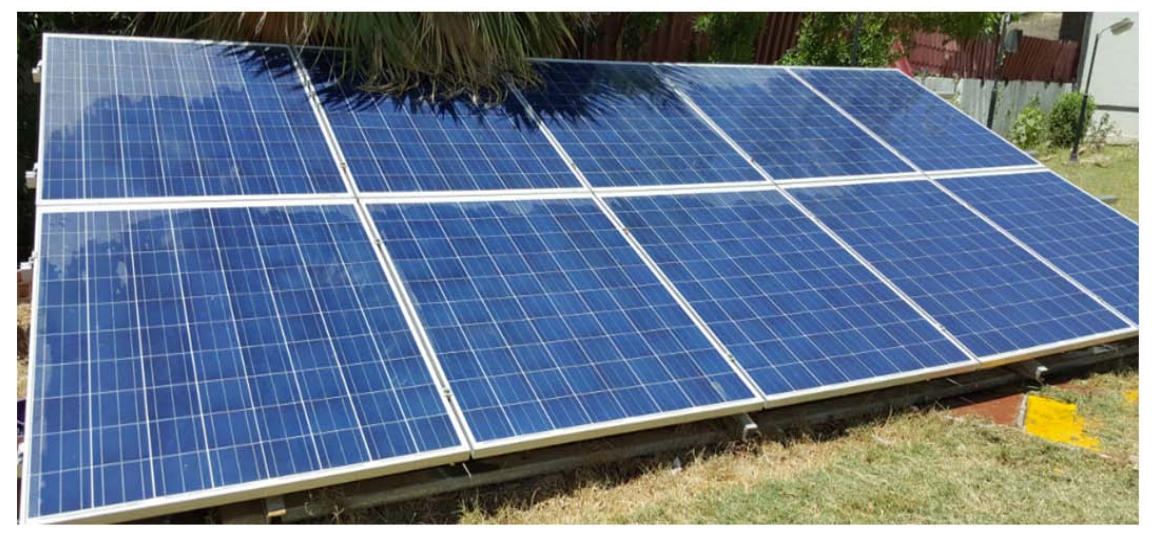

Fig. 13: Solar PV arrays

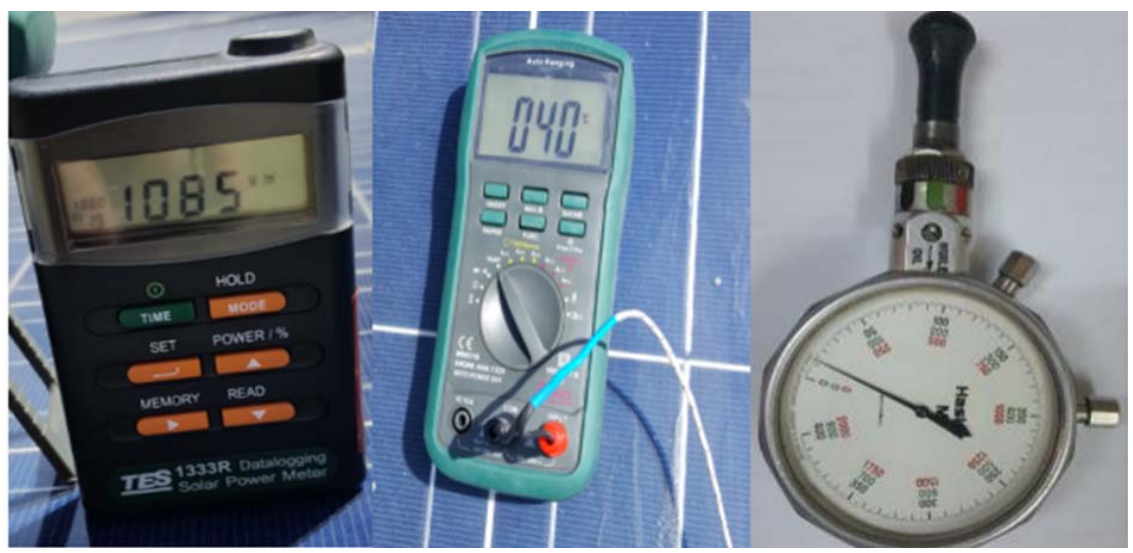

Fig. 14(a-c): Measurment devices, (a) Solar power meter, (b) Temperature sensor and (c) Tacho meter

Figure 18 shown the output voltage from the $\mathrm{PV}$ Array $\mathrm{V}_{\mathrm{PV}}=320 \mathrm{~V}$ for $\mathrm{G}=1085 \mathrm{~W} / \mathrm{m}^{2}$ and $\mathrm{T}=400^{\circ} \mathrm{C}$. Figures 19 shown the line voltages of the 3-phase (I.M) for $\mathrm{G}=1085 \mathrm{~W} / \mathrm{m}^{2}$ and $\mathrm{T}=40^{\circ} \mathrm{C}$. 


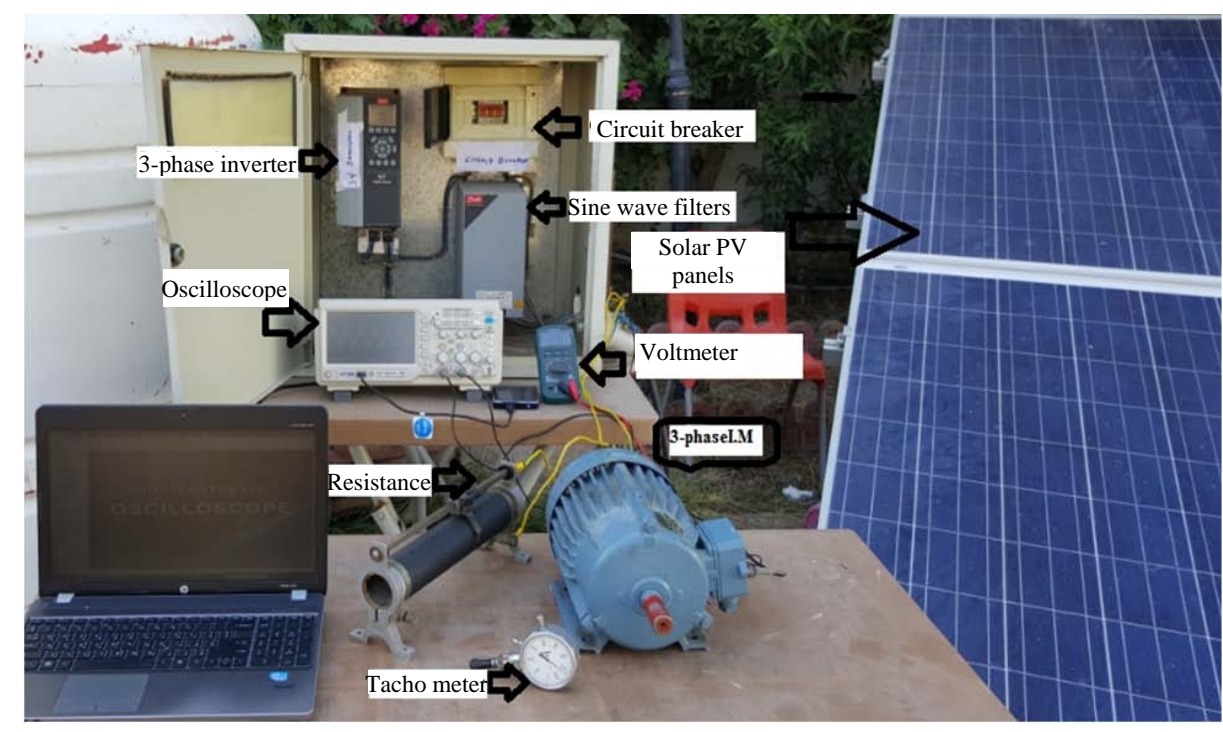

Fig. 15: Experimentation system setup overview

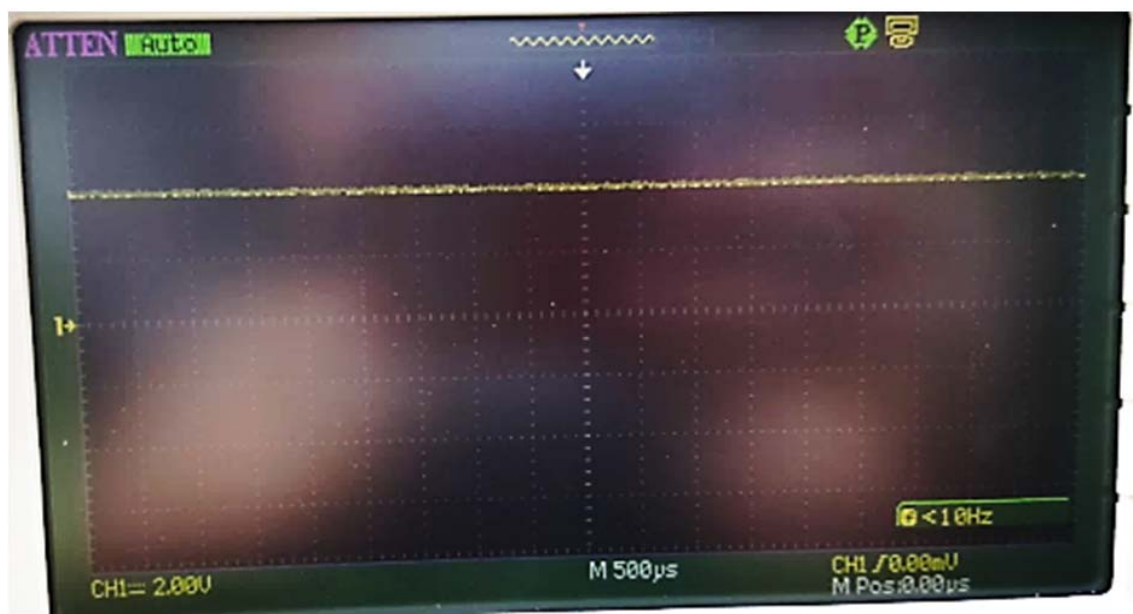

Fig. 16: Output voltage form PV panel using probe (10x)

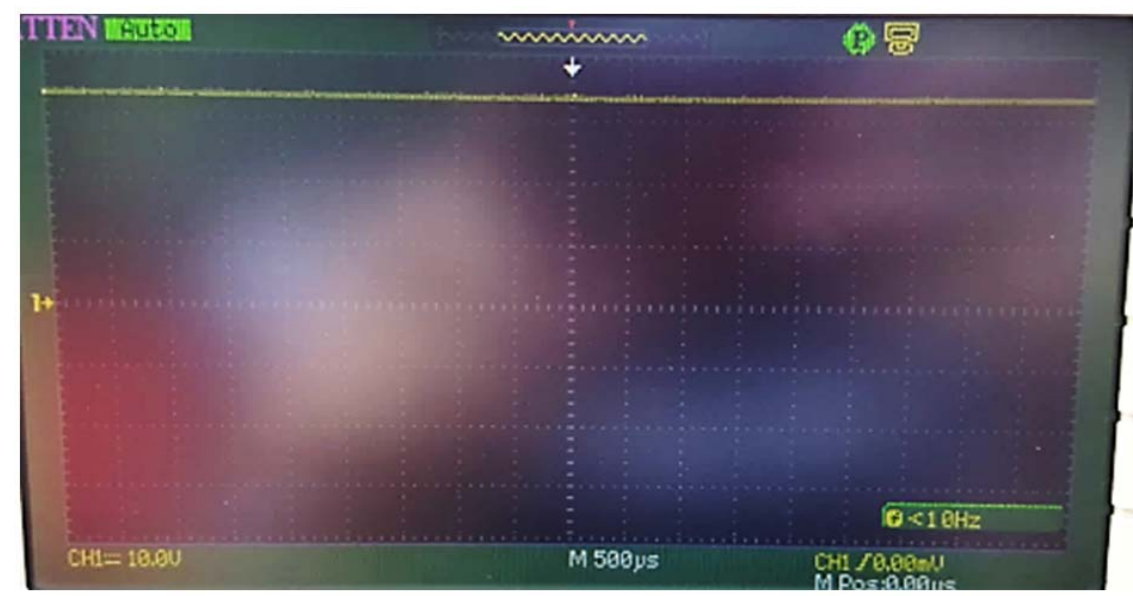

Fig. 17: Output voltage form PV array using probe (10x) 

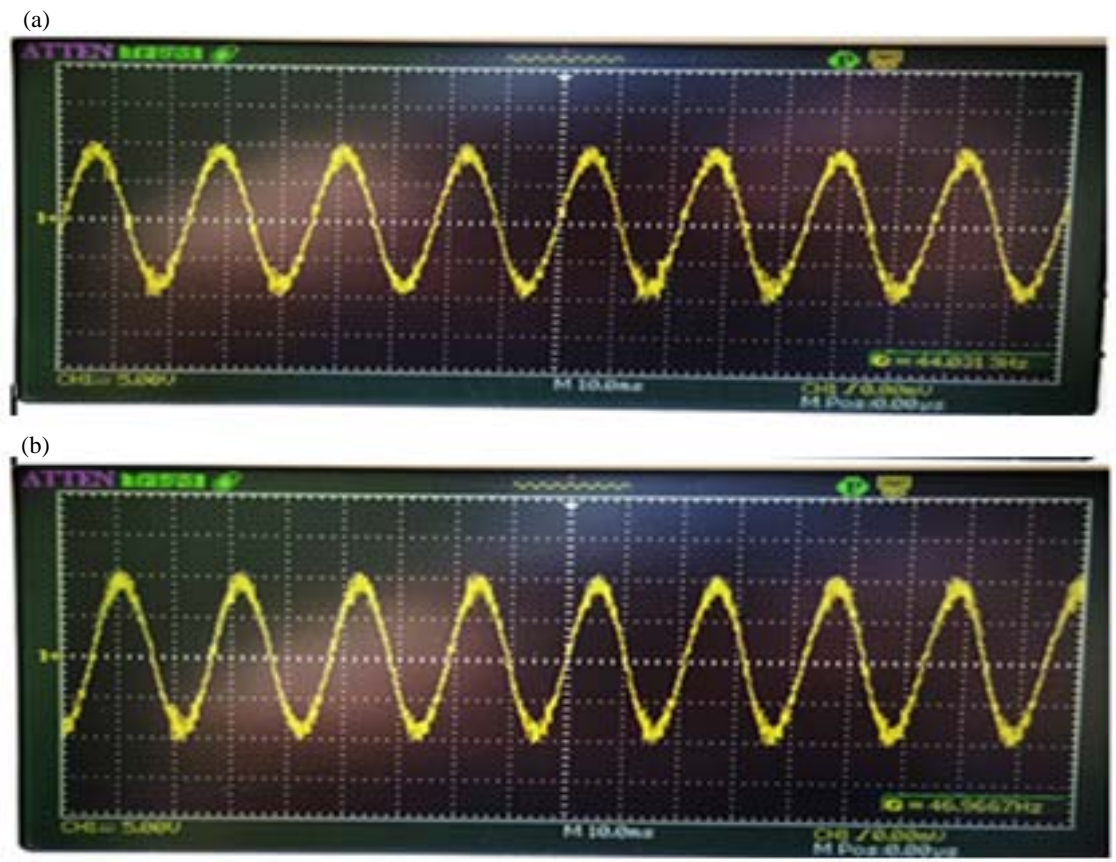

(c)

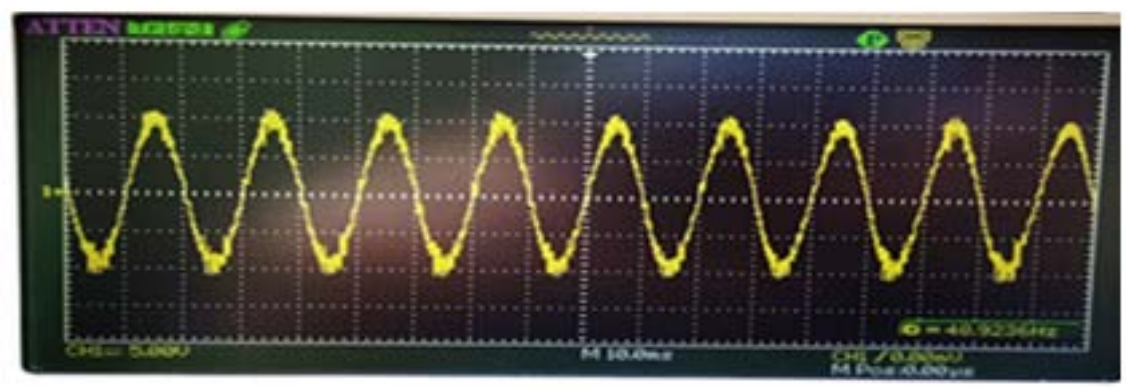

Fig. 18(a-c): Output line to line voltage of 3-phase I.M, (a) Vab, (b) Vbc and (c) Vac

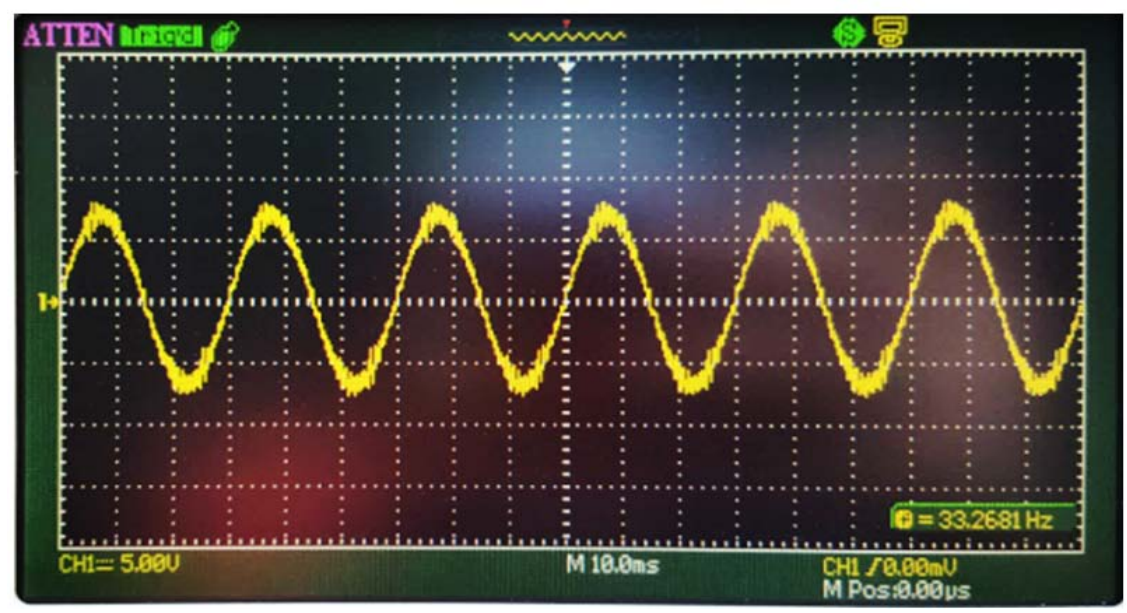

Fig. 19: Output phase voltage of 3-phase I.M (Va)

In addition, the line voltage shows a quite voltage ripple due to various reasons such as neutral connection, motor nonlinear parameters as well as the system is an open loop control. Table 3 shows the experimental results 
J. Eng. Applied Sci., 15 (3): 773-782, 2020

Table 3: Different experimental results for different values of (G\&T)

\begin{tabular}{lccccccc}
\hline $\mathrm{G}\left(\mathrm{W} / \mathrm{m}^{2}\right)$ & $\mathrm{T} / \mathrm{C}^{\circ}$ & $\mathrm{V}_{\mathrm{PV}}(\mathrm{V})$ & $\mathrm{V}_{\mathrm{DC}}(\mathrm{V})$ & $\mathrm{I}_{\mathrm{PV}}(\mathrm{A})$ & $\mathrm{N}$ (r.p.m) & $\mathrm{I}_{\mathrm{L}}(\mathrm{A})$ & $\mathrm{V}_{\mathrm{L}}(\mathrm{V})$ \\
\hline 1005 & 36 & 41.5 & 330 & 7.6 & 2200 & 1.12 & 124 \\
1100 & 41 & 41.0 & 325 & 7.0 & 2100 & 1.10 & 122 \\
1080 & 43 & 40.6 & 322 & 6.9 & 2000 & 1.00 & 120 \\
1130 & 45 & 40.0 & 320 & 6.8 & 1950 & 1.05 & 119 \\
\hline
\end{tabular}

for the output voltage and current of the PV panels and 3-phase (I.M) for different values of irradiance (G) and Temperature $(\mathrm{T})$.

From Table 3, it can concluded that the increasing of the temperature gives small PV voltage in spite of obtaining a good irradiance values. Consequently, the current of the PV panel will decreased. The conditions that given in the table provides a variable inverter line voltages then these output voltages effects on the motor drive speed.

\section{CONCLUSION}

The PV powered induction motor drive can be utilized to drive the centrifugal pump. This drive utilizes VSI inverter for changing over the DC voltage obtained from the PV array to the sinusoidal AC voltage which is acquired by operating the IGBT switches which is controlled by SPWM technique has been designed. Which supplies 3-phase induction motor and its performance has been analyzed. The output waveform clearly shows the effectiveness of the system for various working conditions. The system has been simulated with Simulink MATLAB. First, the simulations of the PV array showed that the simulated models were accurate to determine when the irradiance at STC, the PV array output voltage and current change is shown. The advantage of this system is that it reduces the number of semiconductor switches as there is no DC/DC converters are involved. The experimental results suggest that the proposed solution could be a viable option after more reliability tests are performed to guarantee its robustness.

\section{REFRENCES}

Anjana, A.R., M. Sindhura, C.H. Tarun and M. Sujith, 2017. Solar powered luo converter fed three phase induction motor for water pumping system. Proceedings of the 2017 International Conference on Inventive Systems and Control (ICISC), January 19-20, 2017, IEEE, Coimbatore, India, ISBN:978-1-5090-4716-1, pp: 1-5.

Chenni, R., L. Zarour, A. Bouzid and T. Kerbache, 2006. Comparative study of photovoltaic pumping systems using a Permanent Magnet Synchronous Motor (PMSM) and an asynchronous motor (ASM). Rev. Energ. Ren., 9: 17-28.
Jain, G., A.S., VK and S. Umashankar, 2016. Modelling and simulation of solar photovoltaic fed induction motor for water pumping application using perturb and observer MPPT algorithm. Proceedings of the 2016 International Conference on Energy Efficient Technologies for Sustainability (ICEETS), April 7-8, 2016, IEEE, Nagercoil, India, ISBN:978-1-5090-1534-4, pp: 250-254.

Jones, W.V., 2013. Motor selection made easy: Choosing the right motor for centrifugal pump applications. IEEE. Ind. Appl. Mag., 19: 36-45.

Kumar, K.P. and K. Saikishore, 2013. Analysis and simulation of solar powered water pump using three phase induction motor. Intl. J. Adv. Res. Electr. Electron. Instrum. Eng., 2: 5708-5717.

Kumar, R. and B. Singh, 2017. Single stage solar PV fed brushless DC motor driven water pump. IEEE. J. Emerging Sel. Top. Power Electron., 5: 1377-1385.

Morales, D.S., 2010. Maximum power point tracking algorithms for photovoltaic applications. MSc Thesis, Aalto University, Espoo and Helsinki, Finland.

Pandikumar, M., R. Ramaprabha and R. Muthu, 2015. Performance analysis of the solar photovoltaic fed water pumping system. Aust. J. Basic Appl. Sci., 9: 532-540.

Raju, A.B., S.R. Kanik and R. Jyoti, 2008. Maximum efficiency operation of a single stage inverter fed induction motor $\mathrm{PV}$ water pumping system. Proceedings of the 2008 1st International Conference on Emerging Trends in Engineering and Technology, July 16-18, 2008, IEEE, Nagpur, Maharashtra, India, pp: 905-910.

Ramesh, G., K. Vasavi and S.L. Sirisha, 2014. Photovoltaic cell fed 3-phase induction motor using MPPT technique. Intl. J. Power Electr. Drive Syst., 5: 203-210.

Saini, A.K. and A.K. Dubey, 2017. Performance analysis of single phase induction motor with solar PV array for water pumping system. Intl. J. Eng. Res. Technol., 6: 721-727.

Sharma, A. and A. Parakh, 2018. Design of solar powered induction motor drive for pumping application. Intl. J. Latest Trends Eng. Technol., 10: 228-237.

Singh, M.D. and K.B. Khanchandani, 2008. Power Electronics. 2nd Edn., Tata McGraw-Hill Publishing Co. Ltd, New Delhi, India, ISBN-13:978-0-07-058389-4, Pages: 1071.

Venkatesh, S. and K. Muthukumar, 2017. SEPIC converter based induction motor PV water pumping system. Intl. J. Innovative Res. Sci. Eng. Technol., 6: 14-50.

Zakzouk and N. EzzEldin, 2015. Photovoltaic system design and control. Ph.D Thesis, University of Strathclyde, UK. 